Arq. Bras. Med. Vet. Zootec., v.69, n.1, p.130-138, 2017

\title{
Evaluation of intranasal oxygen supplementation in mules anesthetized with the combination of ketamine, butorphanol, and guaifenesin
}

[Avaliação da suplementação intranasal de oxigênio em muares anestesiados com a associação de cetamina, butorfanol e éter gliceril guaiacólico]

T.J.C. Módolo, M.S. Munerato, G.M. Bueno, G.T. Pereira, J.A. Marques

Faculdade de Ciências Agrárias e Veterinárias - Universidade Paulista - UNESP - Jaboticabal, SP

\begin{abstract}
Hypoxemia is a major complication of field anesthesia and no studies regarding this occurrence in mules has been done. Thus, the aim of this study was to evaluate intranasal oxygen supplementation (IOS) in mules (Equus caballus x Equus asinus) anesthetized with ketamine/butorphanol/guaifenesin combination. For this, we used six male, adult mules $(322 \pm 29 \mathrm{~kg})$ which underwent premedication (MPA) with $0.2 \mathrm{mg} / \mathrm{kg}$ of midazolam intramuscularly after 15 minutes, $0.02 \mathrm{mg} / \mathrm{kg}$ detomidine IV 5 minutes after, induction IV with combination of ketamine $(2 \mathrm{mg} / \mathrm{mL})$, butorphanol $(22.5 \mathrm{mg} / \mathrm{mL})$, and guaifenesin $(50 \mathrm{mg} / \mathrm{mL})(\mathrm{K} / \mathrm{B} / \mathrm{G})$ until lateral decumbency. Maintenance was done with the same anesthetic combination. The animals were submitted twice to the protocol described above, 20 days apart, forming two groups. CG: MPA, induction $(0.92 \pm 0.24 \mathrm{~mL} / \mathrm{kg}(\operatorname{mean} \pm \mathrm{SD}))$, and maintenance $(2.2 \pm 0.2 \mathrm{~mL} / \mathrm{kg} / \mathrm{h})$ without SIO; TG: MPA, induction $(0.98 \pm 0.17 \mathrm{~mL} / \mathrm{kg})$, and maintenance $(2.3 \pm 0.4 \mathrm{~mL} / \mathrm{kg} / \mathrm{h})$ with IOS flow $40 \mathrm{~mL} / \mathrm{kg} / \mathrm{h}$. During anesthesia arterial blood was collected every 20 minutes (T0, T20, T40, and T60) for blood gas analysis. Data analyzed by ANOVA followed by the Bonferroni test. $\mathrm{P}<0.05$ was considered significant. Hypoxemia of the animals in the CG in periods $(59 \pm 5 ; 55 \pm 5 ; 53 \pm 7 ; 49 \pm 8$ ) with lower averages than the TG $(160 \pm 4,115 \pm 34,92 \pm 25,81 \pm 19)$ was observed, demonstrating that IOS increases $\mathrm{PaO}_{2}$ avoiding the occurrence of hypoxemia.
\end{abstract}

Keywords: hypoxemia, IOS, field anesthesia, total intravenously anesthesia, Detomidine

\section{RESUMO}

A hipoxemia é uma das principais complicações da anestesia a campo, e em muares não existem estudos a respeito dessa ocorrência. Assim, objetivou-se avaliar a suplementação intranasal de oxigênio (SIO) em muares (Equus caballus $x$ Equus asinus) anestesiados com cetamina/butorfanol/guaifenesina associados. Para isso, foram utilizados seis muares, macho e adultos $(322 \pm 29 \mathrm{~kg})$, submetidos à medicação pré-anestésica (MPA) com 0,2mg/kg de midazolam por via intramuscular, após 15 minutos, $0,02 \mathrm{mg} / \mathrm{kg}$ de detomidina por via intravenosa, após cinco minutos, indução com administração intravenosa da associação de cetamina $(2 \mathrm{mg} / \mathrm{mL})$, butorfanol $(22,5 \mu \mathrm{g} / \mathrm{mL})$ e guaifenesina $(50 \mathrm{mg} / \mathrm{mL}) \mathrm{em}$ solução de glicose a $5 \%(\mathrm{C} / \mathrm{B} / \mathrm{G})$ até o animal assumir o decúbito lateral. A manutenção foi realizada com a mesma associação anestésica. Os animais foram submetidos duas vezes ao protocolo descrito anteriormente, com intervalo de 20 dias, formando dois grupos experimentais. GC -MPA, indução $(0,92 \pm 0,24 \mathrm{~mL} / \mathrm{kg}$ (média $\pm D P))$ e manutenção $(2,2 \pm 0,2 \mathrm{~mL} / \mathrm{kg} / \mathrm{h})$ sem SIO; GT - MPA, indução $(0,98 \pm 0,17 \mathrm{~mL} / \mathrm{kg})$ e manutenção $(2,3 \pm 0,4 \mathrm{~mL} / \mathrm{kg} / \mathrm{h}) \mathrm{com}$ SIO, fluxo de $40 \mathrm{~mL} / \mathrm{kg} / \mathrm{h}$. Durante a anestesia, foi colhido sangue arterial a cada 20 minutos (T0, T20, T40 e T60) para hemogasometria. Os dados foram analisados pela ANOVA, seguidos pelo teste de Bonferroni. Valores de $P<0,05$ foram considerados significativos. Foi observada hipoxemia $\left(\mathrm{PaO}_{2}<60 \mathrm{mmHg}\right)$ dos animais no GC nos tempos avaliados $(T 0=59 \pm 5 ; T 20=55 \pm 5 ; T 40=53 \pm 7 ; T 60=49 \pm 8)$, com médias menores que as do GT, $(160 \pm 4 ; 115 \pm 34$; 92 $\pm 25 ; 81 \pm 19$, respectivamente), o que demonstrou que a suplementação intranasal de oxigênio aumenta a $\mathrm{PaO}_{2}$, evitando a ocorrência de hipoxemia.

Palavras-chave: hipoxemia, SIO, anestesia a campo, anestesia total intravenosa, detomidina

Recebido em 26 de julho de 2016

Aceito em 28 de julho de 2016

E-mail: tiago.vet10@gmail.com 


\section{INTRODUCTION}

Raising mules is a common practice in many countries, which requires veterinary medical care of these animals at field conditions. Orchiectomy is the main event conducted in field conditions, and due to the behavior of these animals, it requires the use of general anesthesia.

The use of ketamine alone causes hypertonicity, muscle movement cataleptic, and violent recovery (Hellyer et al., 1991). Such effects can be minimized or even eliminated with the combination of sedative, anxiolytic, and muscle relaxants such as midazolam, which is a benzodiazepine and causes minimal physiological effects and cardiovascular stability (Marques et al., 2009). Another drug used in combination with ketamine for induction and maintenance of horses and mules is guaifenesin, which has central action causing great muscle relaxation, and in recommended doses does not cause diaphragm relaxation, allowing animals to breathe spontaneously. It is noteworthy that mules are more sensitive to guaifenesin than horses (Matthews and Taylor, 2000).

Although intravenous anesthesia causes less respiratory depression than inhalation anesthesia (Hubbell and Muir, 2015; McDonell and Kerr, 2007) in general, these animals breathe room air. Therefore, hypoxemia was observed in horses (Yamashita et al., 2007), and in donkeys (Molinaro et al., 2014), and in both studies, the animals were anesthetized with total intravenous anesthesia and breathed room air.

Arterial oxygen pressure $\left(\mathrm{PaO}_{2}\right)$ lower than 60 $\mathrm{mmHg}$ is considered hypoxemia (Robinson, 2009). Maintaining low $\mathrm{PaO}_{2}$ for a long time can lead to lactic acidosis, tissue hypoxemia; myopathies, cell death and collapse of organs.

Hypoventilation and decreased pulmonary blood perfusion are among the possible causes of decreased $\mathrm{PaO}_{2}$ during anesthesia (Yamashita et al., 2007). The first is because most anesthetic drugs decrease the respiration rate and/or tidal volume, resulting in $\mathrm{CO}_{2}$ accumulation in the alveolus and, consequently decreased alveolar $\mathrm{O}_{2}$ concentration, thereby decreasing the alveolar oxygen gradient for blood, producing hypoxemia and hypercapnia (Robinson, 2009).

Arq. Bras. Med. Vet. Zootec., v.69, n.1, p.130-138, 2017
Another fact that interferes with gas exchange is pulmonary ventilation, or the amount of air that reaches the alveoli. The prolonged recumbency on large animals such as horses causes severe compression of the viscera against the diaphragm, hindering ventilation (Hubbel, 2010). With no air in the alveoli, there will be no gas exchange with the blood, or blood enters and leaves the lungs without passing through ventilated alveoli, the so-called right to left vascular shunt (Muir and Hubbel, 2009).

Thus, this study aimed to evaluate the efficacy of intranasal oxygen supplementation (IOS) to increase $\mathrm{PaO}_{2}$ during anesthesia maintenance with ketamine, butorphanol and guaifenesin $(\mathrm{K} / \mathrm{B} / \mathrm{G})$ in mules pre-medicated with intramuscular midazolam and intravenous detomidine to perform orchiectomy in the field.

\section{MATERIALS AND METHODS}

This study was approved by the Ethics Research Committee on Animal Use (CEUA), Faculty of Agricultural and Veterinary Sciences (FCAVUNESP), under protocol number 012888/13. Six male mules aged two and four years and average weight of $322 \pm 29 \mathrm{~kg}$ were used. All were considered healthy by previous clinical and laboratory tests. Handling and the presence of strange people have also been conditioned to the stock to minimize the risk of accidents and better fidelity in data measurement.

Animals underwent orchiectomy performed in two surgical times, one testicle per procedure, with an interval of at least 20 days, thus forming two groups. Control Group (CG): premedication, induction, and maintenance without IOS; Treatment Group (TG): pre-medication, induction, and maintenance with IOS and flow of $40 \mathrm{~mL} / \mathrm{kg} / \mathrm{min}$. Sorting was previously performed to set the test to be surgically removed, and the animal receives or not IOS until all were submitted to the anesthetic protocol previously described, with and without IOS and bilateral orchiectomy.

Approximately 12 hours before anesthesia and surgery, food, but not water, was provided to animals. Then, they were conducted to the stocks and the catheter was inserted in the left jugular vein. For this, the hair over the left jugular vein was previously clipped, the skin was aseptically 
prepared, and local anesthesia was subcutaneously injected. Thus, in an aseptic manner, a central venous catheter, 16G (BD I$\mathrm{Cath}^{\mathrm{TM}}$, Becton Dickinson Indústria Cirúrgica Ltda., MG, Brasil), was introduced into the venous lumen and then secured to the animal's skin using suture.

After insertion of the catheter into the jugular vein, pre-medication was performed with administration of $0.2 \mathrm{mg} / \mathrm{kg}$ midazolam IM $\left(\right.$ Dormonid $^{\circledR}$, Roche, midazolam, Brasil) and after 15 minutes, administration of $0.02 \mathrm{mg} / \mathrm{kg}$ detomidine IV (Dormiun V, Cloridrato de detomidina, União Química Farmacêutica Nacional S/A, Brasil). Thus, five minutes after the IV administration of detomidine, animals were removed from the stock and directed to an external location with grass, simulating field conditions, where anesthesia induction and maintenance was held.

Anesthetic induction was performed with a combination of ketamine $\left(\right.$ Vetaset $^{\circledR}$, Cloridrato de Cetamina, Zoetis Indústria de Produtos Veterinários Ltda., Brasil.), butorphanol (Torbugesic $^{\circledR}$, Tartarato de butorfanol, Fort Dodge Animal Health, USA), and guaifenesin (Guaifenesina, Éter gliceril guaiacol, Henrifarma Produtos Químicos e Farmacêuticos Ltda., Brasil) (K/B/G) (ketamine $2.0 \mathrm{mg} / \mathrm{mL}$, butorphanol $22.5 \mathrm{mg} / \mathrm{mL}$, guaifenesin $50 \mathrm{mg} / \mathrm{mL}$ ), by gravity administration, while maintaining similar height between the bottle with the anesthetic solution and the withers of animals. This combination is administered until they are positioned in the lateral recumbency.

After the placement of animals in right lateral recumbency, anesthesia was initially maintained with $2.1 \mathrm{~mL} / \mathrm{kg} / \mathrm{h}$ of the $\mathrm{K} / \mathrm{B} / \mathrm{G}$ combination for 60 minutes using an infusion pump (DigiPump LP8x, Digicare Animal Helth, EUA). In the TG, an intranasal cannula (Single-lumen tube levine, sinze 12 French and $120 \mathrm{~cm}$ ) was immediately introduced in the ventral meatus of the nostril, until approximately the medial canthus of the eye (Caulket, 2007) for ready administration of $40 \mathrm{~mL} / \mathrm{kg} / \mathrm{min}$ of oxygen.

In the case of anesthetic recovery plan for anesthesia maintenance, resulting in movement of animals, the infusion rate was increased by
$0.1 \mathrm{~mL} / \mathrm{kg} / \mathrm{h}$. During anesthesia maintenance, animals remained in spontaneous ventilation.

Immediately after the beginning of anesthetic maintenance and oxygen administration (in TG), instrumentation of animals for anesthetic monitoring was performed. Thus, the auricular artery or transverse facial artery was aseptically cannulated using 20G (Angiocath $^{\circledR}$, Becton Dickinson Indústria Cirúrgica Ltda., Brasil) catheter for arterial blood sampling and direct blood pressure measurement. The arterial pressure transducer (iPM - 9800, Shenzhen Mindray Bio-Medical Electronics Co. Ltd., China) was attached to the catheter introduced into the arterial lumen and reset taking as reference the sternum of the animal.

After instrumentation, respiratory rate $(f), \mathrm{SpO}_{2}$, heart rate (HR), and systolic (SAP), diastolic (DAP) and mean (MAP) arterial pressure were measured every ten minutes (T0, T10, T20, T30, $\mathrm{T} 40$, and T60) by the invasive method.

Arterial blood samples were anaerobically collected every 20 minutes during anesthesia maintenance (T0, T20, T40, and T60). Arterial blood gas analysis was held immediately after collection of arterial blood using i-STAT cards model $\mathrm{CG}^{+}{ }^{+}$i-STAT $^{\circledR}$ Cartridge $\mathrm{CG}_{4}{ }^{+}$, Abbot Point of Care Inc., EUA), in portable blood gas analyzer (i-STAT ${ }^{\circledR}$, Acid Base Laboratory 330, Copenhagen Denmark), in order to measure the partial oxygen pressure $\left(\mathrm{PaO}_{2}\right)$, partial carbon dioxide pressure $\left(\mathrm{PaCO}_{2}\right), \mathrm{pH}$, base excess $(\mathrm{BE})$, concentration of bicarbonate ions $\left(\mathrm{HCO}_{3}\right)$ and lactate.

As painful stimulus, at $\mathrm{T} 30$ proceeded to orchiectomy of one testicle, as previously mentioned. At the end of 60 minutes of anesthesia monitoring, $\mathrm{K} / \mathrm{B} / \mathrm{G}$ infusion interrupted, as well as the administration of IOS in animals from TG. Then, mules were transferred to the recovery room and an experienced veterinarian observed throughout the recovery process.

Data for cardiorespiratory variables and arterial blood gas analysis were analyzed using repeated analysis of variance (ANOVA) measures followed by Bonferroni correction test for multiple comparisons among monitoring times for each experimental group (TG and CG) and 
interaction between these groups. Data presented are the original mean values \pm SD. Statistical analyses were performed using SAS 9.1 software (Statistical, 2004). Values are expressed as mean \pm SD and $\mathrm{P}$ values $<0.05$ were considered significant.

\section{RESULTS}

The dose of $\mathrm{K} / \mathrm{B} / \mathrm{G}$ combination required to induce anesthesia in animals submitted to CG was $0.92 \pm 0.24 \mathrm{~mL} / \mathrm{kg}$ and $\mathrm{TG} 0.98 \pm 0.17 \mathrm{~mL} / \mathrm{kg}$.
The average infusion rate for anesthesia maintenance was $2.2 \pm 0.2 \mathrm{~mL} / \mathrm{kg} / \mathrm{h}$ for $\mathrm{CG}$ and $2.3 \pm 0.4 \mathrm{~mL} / \mathrm{kg} / \mathrm{h}$ for $\mathrm{TG}$. There was no difference between groups for the mean $\mathrm{K} / \mathrm{B} / \mathrm{G}$ doses used for anesthesia or the mean infusion rate for anesthesia maintenance. There was no difference in the instrumentation time for the $\mathrm{CG}$, which took on average $17 \pm 6$ minutes and TG $16 \pm 3$ minutes to puncture the artery and instrumentation of animals. The average HR, SAP, DAP, MAP, $f$ and $\mathrm{SpO}_{2}$ values are shown in Table 1.

Table 1. Mean \pm SD of cardiorespiratory variables (heart rate (HR), systolic (SAP), diastolic (DAP) and mean arterial pressure (MAP), respiratory rate $(f)$ and $\mathrm{SpO} 2)$, pre-medicated with midazolam and detomidine with and without IOS (TG and CG, respectively)

\begin{tabular}{|c|c|c|c|c|c|c|c|c|}
\hline \multirow{2}{*}{ Variable } & \multirow{2}{*}{$\begin{array}{c}\text { Grou } \\
\mathrm{p} \\
\end{array}$} & \multicolumn{7}{|c|}{ Anesthetic Maintenance } \\
\hline & & T0 $(n)$ & T10 $(n)$ & T20 (n) & T30 $(n)$ & T40 (n) & T50 (n) & T60 (n) \\
\hline \multirow{12}{*}{$\begin{array}{c}\mathrm{HR}^{\dagger} \\
(\mathrm{bat} / \mathrm{min}) \\
\mathrm{SAP}^{\dagger} \\
\left(\mathrm{mmHg}^{\dagger}\right) \\
\mathrm{DAP}^{\dagger} \\
\left(\mathrm{mmHg}^{\circ}\right) \\
\mathrm{MAP}^{\dagger} \\
\left(\mathrm{mmHg}^{\dagger}\right) \\
f^{\dagger} \\
\left(\mathrm{mov}^{\prime} \mathrm{min}\right) \\
\mathrm{SpO}_{2} \\
(\%)\end{array}$} & $\mathrm{CG}$ & (6) $38 \pm 3$ & (6) $40 \pm 4$ & (6) $42 \pm 5$ & (6) $46 \pm 6$ & (6) $48 \pm 5$ & (6) $50 \pm 5$ & (6) $49 \pm 6$ \\
\hline & TG & (6) $37 \pm 6$ & (6) $38 \pm 6$ & (6) $39 \pm 7$ & (6) $40 \pm 5$ & (6) $42 \pm 8$ & (6) $47 \pm 7$ & (6) $43 \pm 7$ \\
\hline & CG & (6) $135 \pm 14$ & (6) $126 \pm 12$ & (6) $118 \pm 10$ & (6) $113 \pm 19$ & (6) $109 \pm 29$ & (6) $113 \pm 33$ & (6) $118 \pm 34$ \\
\hline & TG & (6) $121 \pm 9^{a}$ & (6) $111 \pm 11^{\mathrm{ab}}$ & (6) $103 \pm 11^{\mathrm{ab}}$ & (6) $96 \pm 10^{\mathrm{ab}}$ & (6) $91 \pm 11^{\mathrm{b}}$ & (6) $89 \pm 13^{b}$ & (6) $89 \pm 11^{\mathrm{b}}$ \\
\hline & CG & (6) $110 \pm 44$ & (6) $92 \pm 10$ & (6) $86 \pm 11$ & (6) $76 \pm 18$ & (6) $70 \pm 25$ & (6) $77 \pm 30$ & (6) $85 \pm 30$ \\
\hline & TG & (6) $84 \pm 3^{a}$ & (6) $75 \pm 7^{\mathrm{ab}}$ & (6) $67 \pm 10^{\mathrm{ab}}$ & (6) $62 \pm 10^{\mathrm{ab}}$ & (6) $56 \pm 14^{\mathrm{ab}}$ & (6) $55 \pm 16^{\mathrm{b}}$ & (6) $56 \pm 8^{\mathrm{ab}}$ \\
\hline & $\mathrm{CG}$ & (6) $105 \pm 9$ & (6) $103 \pm 9$ & (6) $97 \pm 11$ & (6) $87 \pm 16$ & (6) $84 \pm 26$ & (6) $88 \pm 30$ & (6) $96 \pm 31$ \\
\hline & TG & (6) $96 \pm 5^{\mathrm{a}}$ & (6) $87 \pm 8^{\mathrm{ab}}$ & (6) $78 \pm 10^{\mathrm{ab}}$ & (6) $74 \pm 10^{\mathrm{ab}}$ & (6) $67 \pm 13^{b}$ & (6) $67 \pm 16^{\mathrm{b}}$ & (6) $67 \pm 10^{\mathrm{b}}$ \\
\hline & $\mathrm{CG}$ & (6) $20 \pm 4$ & (6) $19 \pm 4$ & (6) $18 \pm 4$ & (6) $16 \pm 12$ & (6) $17 \pm 5$ & (6) $18 \pm 5$ & (6) $18 \pm 5$ \\
\hline & TG & (6) $18 \pm 7$ & (6) $14 \pm 6$ & (6) $12 \pm 5$ & (6) $15 \pm 6$ & (6) $13 \pm 3$ & (6) $13 \pm 7$ & (6) $12 \pm 4$ \\
\hline & $\mathrm{CG}$ & (6) $91 \pm 3^{a}$ & (6) $90 \pm 3^{\mathrm{ac}}$ & (6) $89 \pm 3^{\text {Aab }}$ & (6) $87 \pm 4^{\text {Aab }}$ & (6) $86 \pm 3^{\mathrm{Aab}}$ & (6) $85 \pm 4^{\mathrm{Aac}}$ & (6) $85 \pm 4^{\mathrm{Ab}}$ \\
\hline & TG & (6) $98 \pm 2$ & (6) $96 \pm 1$ & (6) $96 \pm 3^{\mathrm{B}}$ & (6) $96 \pm 2^{\mathrm{B}}$ & (6) $95 \pm 2^{\mathrm{B}}$ & (6) $95 \pm 2^{\mathrm{B}}$ & (6) $95 \pm 2^{\mathrm{B}}$ \\
\hline
\end{tabular}

Values followed by upper case letters indicate differences between groups. Values followed by lowercase letters indicate differences among monitoring times in a given group.

${ }^{\dagger}$ Logarithmic transformation was used in the statistical analysis. Values represented in the table are the mean \pm SD original without logarithmic transformation.

Arterial blood pressure (systolic, diastolic and mean) showed a significant difference among monitoring times only in TG. For SAP and MAP, T0 was higher than T40, T50, and T60. The diastolic arterial pressure in $\mathrm{T} 0$ was higher than T50.

$\mathrm{SpO}_{2}$ (Figure 1; Table 1) at $\mathrm{T} 0$ of $\mathrm{CG}$ showed higher averages compared to averages of T50 and T60, T10 was only higher than T60. In TG, no difference among monitoring times was observed. Among groups, TG showed higher mean values in all measurements when compared to GC, showing a significant difference at all times from T20 (T20, T30, T40, T50, and T60). $\mathrm{PaO}_{2}$ (Table 2, Figure 2) was significantly higher in the group with supplementation at all times in which it was assessed (T0, T20, T40, T60).
There was no significant difference in the mean $f$ and $\mathrm{HR}$ values. $\mathrm{PaCO}_{2}$ value was lower $(\mathrm{P}=0.03)$ in $\mathrm{CG}$ at $\mathrm{T} 0$ compared to TG at T0.

Lactate and bicarbonate measured in the arterial blood showed no significant difference and average $\mathrm{pH}$ values increased with a significant difference in the $\mathrm{CG}(\mathrm{P}=0.02)$ between $\mathrm{T} 0$ and $\mathrm{T} 60$ and in the TG between T0 and T40 $(\mathrm{P}=0.03)$ and $\mathrm{T} 60(\mathrm{P}=0.002)$. The mean $\pm \mathrm{SD}$ values of arterial blood gas analysis are shown in Table 2.

No difference was found in induction time, as well as the time interval between the end of continuous infusion and the first animal movement. There was no difference between groups for the sternal decumbency and standing position (recovery anesthetic). 
Table 2. Mean \pm SD of blood hemogasometry of mules anesthetized with combination of ketamine/butorphanol/guaifenesin $(\mathrm{K} / \mathrm{B} / \mathrm{G})$, pre-medicated with midazolam and detomidine with and without IOS (TG and CG, respectively)

\begin{tabular}{cccccc}
\multirow{2}{*}{ Variable } & Group & \multicolumn{5}{c}{ Times } \\
\cline { 3 - 5 } & & \multicolumn{1}{c}{ T0 $(n)$} & \multicolumn{1}{c}{ T20 $(n)$} & \multicolumn{1}{c}{ T40 $(n)$} & T60 $(n)$ \\
\hline Lactate & CG & $(6) 1,8 \pm 0,9$ & $(6) 1,7 \pm 0,8$ & $(6) 1,5 \pm 0,6$ & $(6) 1,4 \pm 0,6$ \\
$(\mathrm{mmol} / \mathrm{L})$ & TG & $(6) 1,4 \pm 0,9$ & $(6) 1,2 \pm 0,6$ & $(6) 1,2 \pm 0,5$ & $(6) 1,2 \pm 0,5$ \\
$\mathrm{pH}$ & $\mathrm{CG}$ & $(6) 7,32 \pm 0,03^{\mathrm{a}}$ & $(6) 7,34 \pm 0,003^{\mathrm{ab}}$ & $(6) 7,35 \pm 0,05^{\mathrm{ab}}$ & $(6) 7,36 \pm 0,05^{\mathrm{b}}$ \\
& TG & $(6) 7,28 \pm 0,02^{\mathrm{a}}$ & $(6) 7,30 \pm 0,04^{\mathrm{ab}}$ & $(6) 7,31 \pm 0,04^{\mathrm{b}}$ & $(6) 7,32 \pm 0,03^{\mathrm{b}}$
\end{tabular}

$\begin{array}{clllll}\mathrm{HCO}_{3}^{-\dagger} & \mathrm{CG} & (6) 26,5 \pm 12,4 & (6) 25,0 \pm 1,0 & (6) 25,0 \pm 2,5 & (6) 25,0 \pm 2,5 \\ (\mathrm{mmol} / \mathrm{L}) & \mathrm{TG} & (6) 24,3 \pm 2,4 & (6) 24,85 \pm 1,9 & (6) 25,8 \pm 2,6 & (6) 26,8 \pm 2,0 \\ \mathrm{BE} & \mathrm{CG} & (6)-4 \pm 3^{\mathrm{a}} & (6)-1 \pm 1^{\mathrm{b}} & (6)-1 \pm 3^{\mathrm{b}} & (6)-1 \pm 3^{\mathrm{b}} \\ (\mathrm{mmol} / \mathrm{L}) & \mathrm{TG} & (6)-2 \pm 3^{\mathrm{ab}} & (6)-3 \pm 2^{\mathrm{a}} & (6)-1 \pm 3^{\mathrm{ab}} & (6) 1 \pm 2^{\mathrm{b}} \\ \mathrm{PaCO}_{2} & \mathrm{CG} & (6) 41,5 \pm 4,7^{\mathrm{A}} & (6) 46,3 \pm 3,3 & (6) 45,5 \pm 4,4 & (6) 44,1 \pm 5,7 \\ (\mathrm{mmHg}) & \mathrm{TG} & (6) 51,8 \pm 3,4^{\mathrm{B}} & (6) 49,0 \pm 5,0 & (6) 50,7 \pm 5,8 & (6) 51,5 \pm 6,3 \\ \mathrm{PaO}_{2} & \mathrm{CG} & (6) 59 \pm 5^{\mathrm{A}} & (6) 55 \pm 5^{\mathrm{A}} & (6) 53 \pm 7^{\mathrm{A}} & (6) 49 \pm 8^{\mathrm{A}} \\ (\mathrm{mmHg}) & \mathrm{TG} & (6) 160 \pm 34^{\mathrm{Ba}} & (6) 115 \pm 34^{\mathrm{Ba}} & (6) 92 \pm 25^{\mathrm{Bbc}} & \text { (6) } 81 \pm 19^{\mathrm{Bc}}\end{array}$

Values followed by upper case letters indicate differences between groups. Values followed by lowercase letters indicate differences among monitoring times in a given group.

${ }^{\dagger}$ Logarithmic transformation was used in the statistical analysis. Values represented in the table are the mean \pm SD original without logarithmic transformation.

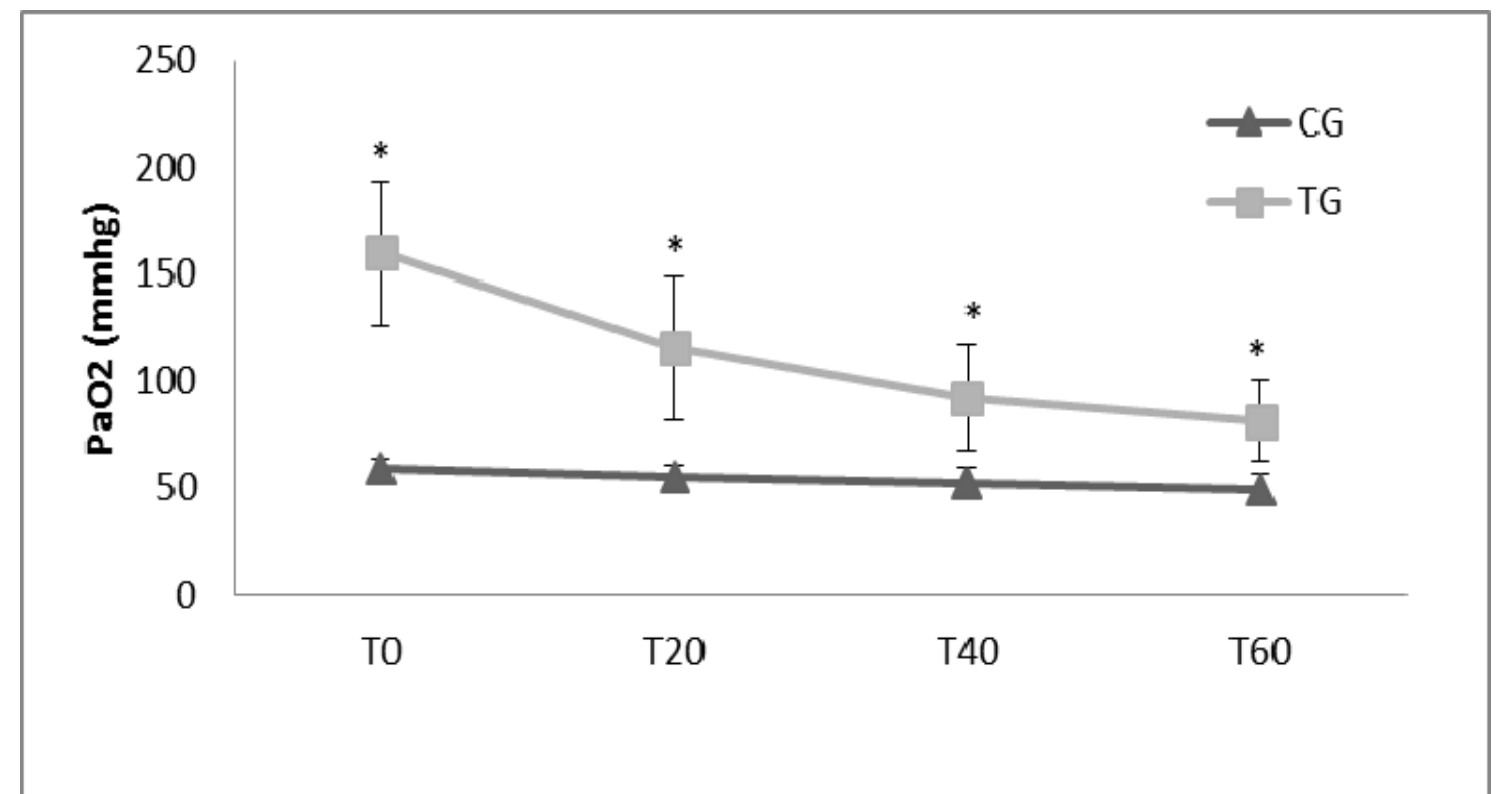

Figure 1. $\mathrm{SpO}_{2}$ of mules anesthetized with combination ketamine/butorphanol/Guaifenesin (K/B/G), premedicated with midazolam and detomidine with and without IOS (CG and TG, respectively). * Indicates the times that there was difference $(\mathrm{P}<0.05)$ between groups. 


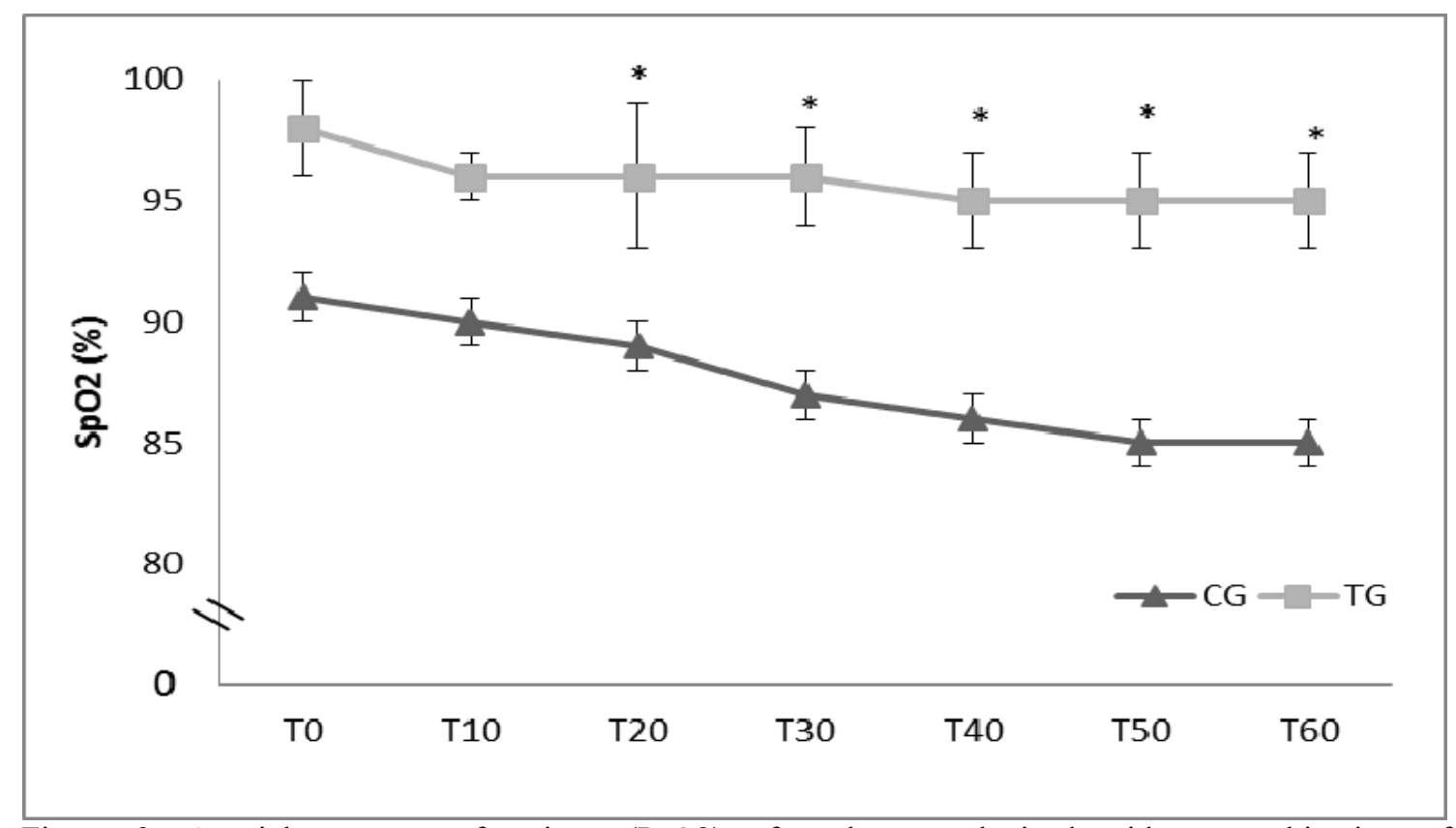

Figure 2. Arterial pressure of oxigen $(\mathrm{PaO} 2)$ of mules anesthetized with a combination of ketamine/butorphanol/Guaifenesin $(\mathrm{K} / \mathrm{B} / \mathrm{G})$, pre-medicated with midazolam and detomidine with and without IOS (CG and TG, respectively). * Indicates the times that there was difference $(\mathrm{P}<0.05)$ between groups.

\section{DISCUSSION}

The main occurrence in this study was hypoxemia in mules anesthetized with $\mathrm{K} / \mathrm{B} / \mathrm{G}$ receiving no IOS, since animals were supplemented with intranasal oxygen, which kept $\mathrm{PaO}_{2}$ values within acceptable levels, as shown in Table 2. The probable causes of decreased $\mathrm{PaO}_{2}$ are hypoventilation, vascular shunt and ventilation-perfusion mismatching (Hubbell, 2010).

In this study, it could not be concluded that the cause of decreased $\mathrm{PaO}_{2}$ values in $\mathrm{CG}$ was hypoventilation due to variation in respiratory rate among times or between groups. Another fact that confirms the non-occurrence of hypoventilation are the $\mathrm{PaCO}_{2}$ values, decreased ventilation causes deficiency in $\mathrm{CO}_{2}$ elimination, thereby occurring the accumulation of this gas, causing hypercapnia (Muir and Hubbell, 2009; Robinson, 2009). Normal $\mathrm{PaCO}_{2}$ values are 40$45 \mathrm{mmHg}$, values of 60 to $70 \mathrm{mmHg}$ are commonly observed during anesthesia inhalation of horses, such moderate elevation promotes desirable effects by stimulation of the sympathetic system, resulting in increased cardiac output (Muir and Hubbell, 2009). However, in sedated horses maintained with guaifenesin in lateral recumbence, there was no change in $\mathrm{PaCO}_{2}$ (Schatzmann et al., 1982). $\mathrm{PaCO}_{2}$ values for mules anesthetized with $\mathrm{K} / \mathrm{B} / \mathrm{G}$ remained stable over time, with a significant difference between groups only at T0, but these values are not considered high, so it could be inferred that there was no $\mathrm{CO}_{2}$ accumulation in the arterial blood of these mules.

As for the vascular shunt or right to left shunt, it is probably one of the causes of hypoxemia in mules from the group not receiving oxygen supplementation. Shunt may be due to areas of atelectasis, i.e., blood flow in non-ventilated alveoli. Atelectasis can occur in anesthetized horses due to high fraction of inspired oxygen or simply to animal recumbency (Hubbel and Muir, 2015; Hubbell et al., 2011). When the animal is breathing $100 \% \mathrm{O}_{2}$, there will only be oxygen in the alveoli, and as it is easily diffused to the blood, the alveoli tends to collapse, causing absorption atelectasis. This was the probable cause of the decrease in $\mathrm{PaO}_{2}$ in the TG along of anesthesia. Hubbell et al. (2011), suggested reducing $\mathrm{FiO}_{2}$ to 0.5 in order to reduce the 
occurrence of shunt caused by the absorption atelectasis, however, $\mathrm{PaO}_{2}$ decreased without a significant improvement in shunt fraction or alveolar dead space ventilation.

However, the cause of the decrease in $\mathrm{PaO}_{2}$ may be the recumbency, due to weight and position of the diaphragm under the viscera, which compresses the lungs and consequently causes compression atelectasis (Hubbell and Muir, 2015; Hubbell, 2010). Recumbency also reduces the functional residual capacity, which corresponds to the amount of air that remains in the lungs after the end of expiration, according to McDonell and Kerr (2007), thus contributing to decrease $\mathrm{PaO}_{2}$. Furthermore, when the animal is placed in lateral recumbency, the dependent lung is the most affected, not only due to the compression of the diaphragm and internal organs, but also to the contralateral lung (McDonell and Kerr 2007). The increase in $\mathrm{FiO}_{2}$ in mules from the $\mathrm{TG}$ does not reduce the occurrence of atelectasis or reduce the compression caused by viscera, diaphragm, and contralateral lung. IOS prevented the development of hypoxia by increasing the oxygen supply in the alveoli, thereby increasing the oxygen absorption by the blood.

One way to monitor the arterial blood oxygen concentration is by $\mathrm{SpO}_{2}$ (Caulkett, 2007). This refers to the percentage of saturation of hemoglobin by oxygen, and their values are related to the $\mathrm{PaO}_{2}$ values (Haskins, 2007). The results of this study were similar, and in the $\mathrm{CG}$, the mean $\mathrm{SpO}_{2}$ values at the beginning of anesthetic maintenance (T0) were closer to $90 \%$ $(91 \pm 3 \%)$ and the mean $\mathrm{PaO}_{2}$ values at the same time were $59 \pm 5 \mathrm{mmHg}$. At the end of the anesthetic maintenance, values were, respectively, $85 \pm 4 \%$ and $49 \pm 8 \mathrm{mmHg}$; therefore, by analyzing these values and the others represented in Tables 1 and 2 , it could be inferred that animals from the $\mathrm{CG}$ had hypoxemia $\left(\mathrm{PaO}_{2}<60 \mathrm{mmHg}\right)$ throughout anesthesia.

In contrast, the average $\mathrm{SpO}_{2}$ values of $\mathrm{TG}$ were greater than $90 \%$ since the beginning of anesthetic maintenance (T0) by the end of anesthesia (T60), and the $\mathrm{PaO}_{2}$ values were higher than $60 \mathrm{mmHg}$ at all times in which they were measured, proving the importance of intranasal oxygen supplementation to prevent the occurrence of hypoxemia in anesthetized mules under field conditions. Marntell et al. (2005) demonstrated that oxygen supplementation in horses anesthetized with tiletamine-zolazepam after pre-medication with acepromazine, butorphanol, and romifidine increases the $\mathrm{PaO}_{2}$ values when compared to horses that received the same anesthetic but with air breathing. Likewise, Caulkett (2007) suggested that intranasal oxygen supplemental at flow rate of 10 to 15 liters/minute, keep $\mathrm{SpO}_{2}$ values over $95 \%$ in horses anaesthetized under field conditions and that for animals with $\mathrm{SpO}_{2}<90 \%$, oxygen supplementation is indicated, and when $\mathrm{SpO}_{2}<80 \%$, animals should be supplemented with oxygen.

The respiratory rate remained statistically unchanged for all measurements taken both in CG and in TG. In contrast, Marntell et al. (2005) observed that horses breathing high oxygen concentrations $\left(\mathrm{FiO}_{2}>0.95\right)$ during dissociative anesthesia had lower respiratory rate and higher $\mathrm{PaCO}_{2}$ values when compared to animals with air breathing $\left(\mathrm{FiO}_{2}=0.21\right)$. This probably occurs because ventilation control is mainly determined by the response to $\mathrm{CO}_{2}$ chemoreceptor in the CNS and peripheral $\mathrm{O}_{2}$, but anesthetic drugs such as ketamine and butorphanol used in this study can cause depression of these respiratory centers, decreasing the response of $\mathrm{CO}_{2}$ chemoreceptor (McDonell and Kerr, 2007). With the response to decreased $\mathrm{CO}_{2}$ and without $\mathrm{PaO}_{2}$ decreasing to critical levels due to oxygen supplementation, the respiratory rate will not increase, resulting in hypoventilation and hypercapnia (Paterson et al., 2009).

The average $\mathrm{pH}$ and $\mathrm{BE}$ values increased during anesthesia. Low $\mathrm{pH}$ values were only observed in $\mathrm{T} 0$ of the TG, an unlikely hypothesis in this case is due to respiratory acidosis caused by the elevation of $\mathrm{PaCO}_{2}$. The increase in $\mathrm{CO}_{2}$ concentration in the plasma, which may be caused by hypoventilation, may lead to decreased blood $\mathrm{pH}$, causing respiratory acidosis, because when carbon dioxide combines with water to form carbonic acid $\left(\mathrm{H}_{2} \mathrm{CO}_{3}\right)$, it dissociates to form hydrogen ion $\left(\mathrm{H}^{+}\right)$and bicarbonate $\left(\mathrm{HCO}_{3}{ }^{-}\right)$(Corley and Marr, 1998). In contrast, if it was the cause of the decrease in $\mathrm{pH}$ in the present study, there would be a compensatory elevation of bicarbonate following $\mathrm{PaCO}_{2}$. Another hypothesis for the lowest mean 
$\mathrm{pH}$ values at the beginning of anesthesia is the stress caused by the manipulation of mules. Thus, glucose metabolism may have occurred anaerobically with pyruvate with lactic fermentation, releasing lactic acid (lactate and $\mathrm{H}^{+}$) and decreasing the values of arterial blood pH (Teixeira Neto, 2011).

In another study carried out by Taylor (1999), little effect of hypoxia on endocrine and metabolic response in anesthetized ponies has been reported, but there was an increase of lactate in animals with hypoxemia, demonstrating the occurrence of anaerobic metabolism in these animals. Equidae, in general, are adapted to support hypoxemia during exercise and can tolerate low $\mathrm{PaO}_{2}$ values (55-60 $\mathrm{mmHg}$ ) without major systemic changes (Pelletier and Leith, 1995). However, the use of anesthetic drugs decreases the compensatory response of oxygen fluctuations, $\mathrm{pH}$ and carbon dioxide, and causes splenic dilation that reduces the amount of circulating red blood cells (McDonell and Kerr, 2007). Thus, intranasal oxygen supplementation may be supplied to reduce compensatory responses of mules.

\section{CONCLUSIONS}

Based on the analysis of cardiovascular parameters and blood gas analysis of arterial blood, it could be concluded that intranasal oxygen supplementation maintained $\mathrm{PaO}_{2}$ at acceptable levels, avoiding the occurrence of hypoxemia in supplemented animals. Thus, when applying total intravenous anesthesia with combination of ketamine, butorphanol and guaifenesin in mules, the use of intranasal oxygen supplemental with flow rate of $40 \mathrm{~mL} / \mathrm{kg} / \mathrm{min}$ is recommended.

\section{ACKNOWLEDGMENTS}

This work was carried out with CNPq support, the National Council for Scientific and Technological Development - Brazil.

\section{REFERENCES}

CAULKETT, N. Equine field anesthesia and sedation. Large Anim. Vet. Rounds, v.7, p.6, 2007.

CORLEY, K.T.T.; MARR, C.M. Pathophysiology, assessment and treatment of acid-base disturbances in the horse. Equine Vet. Educ., v.10, p.255-265, 1998.

HASKINS, S.C. Monitoring anesthetized patients, In: TRANQUILI, W.J.; THURMON, J.C.; GRIMM, K.A. (Eds.). Lumb \& Jones veterinary anesthesia and analgesia. Ames: Blackwell Publishing, 2007. p.533-560.

HELLYER, P.W.; FREEMAN, L.C.; HUBBELL, J.A.E. Induction of anesthesia with diazepamketamine and midazolam-ketamine in greyhounds. Vet. Surg., v.20, p.143-147, 1991.

HUBBELL, J.A.E. Review of support of ventilation in the anesthetized horse. In: ANNUAL CONVENTION OF THE AMERICAN ASSOCIATION OF EQUINE PRACTICERS, 56., 2010, Baltimore. Proceedings... Baltimore: American Association of Equine Practitioners, 2010. p.33-37.

HUBBELL, J.A.E.; AARNES, T.K.; BEDNARSKI, R.M. et al. Effect of $50 \%$ and maximal inspired oxygen concentrations on respiratory variables in isoflurane-anesthetized horses. BMC Vet. Res., v.7, p.23, 2011.

HUBBELL, J.A.E.; MUIR, W.W. Oxygenation, oxygen delivery and anaesthesia in the horse. Equine Vet. J., v.47, p.25-35, 2015.

MARNTELL, S.; NYMAN, G.; HEDENSTIERNA, G. High inspired oxygen concentrations increase intrapulmonary shunt in anaesthetized horses. Vet. Anaesth. Analg., v.32, p.338-347, 2005.

MARQUES, J.A.; PEREIRA, D.A.; MARQUES, I.C.S. Associação entre midazolam e detomidina na medicação pré-anestésica para indução da anestesia geral com cetamina em potros. Arq. Bras. Med. Vet. Zootec., v.61, p.1290-1296, 2009. 
MATTHEWS, N.; TAYLOR, T. Anesthetic management of donkeys and mules. In. Steffey, E.P. (Ed.). Recent advances in anesthetic management of large domestic animal. Texas: International Veterinary Information Service, 2000. Available in: <http://www.ivis.org>. Accessed in: 30 jun. 2015.

McDONELL, W.N.; KERR, C.L. Respiratory system, In: TRANQUILLI, W.J.; THURMON, J.C.; GRIMM, K.A. (Eds.). Lumb \& Jones veterinary anesthesia and analgesia. Ames: Blackwell Publishing, 2007. p.117-151.

MOLINARO, C.C.M.; DUQUE, M.J.C.; GOULART, D.D.S. et al. Evaluation of cardiorespiratory and biochemical effects of ketamine-propofol and guaifenesin-ketaminexylazine anesthesia in donkeys (Equus asinus). Vet. Anaesth. Analg., v.41, p.602-12, 2014.

MUIR, W.W.; HUBBELL, J.A.E. Anestheticassociated complications: equine anesthesia: monitoring and emergency therapy. [St Louis]: Elsevier, 2009. p.397-417.

PATERSON, J.M.; CAULKETT, N.A.; WOODBURY, M.R. Physiologic effects of nasal oxygen or medical air administered prior to and during carfentanil-xylazine anesthesia in North American elk (Cervus canadensis manitobensis). J. Zoo Wildl. Med. v.40, p.39-50, 2009.
PELLETIER, N.; LEITH, D.E. Ventilation and carbon dioxide exchange in exercising horses: effect of inspired oxygen fraction. J. Appl. Physiol., v.78, p.654-662, 1995.

ROBINSON, N.E. The respiratory system equine anesthesia: monitoring and emergency therapy. St Louis: Elsevier, 2009. p.11-36.

SCHATZMANN, U.; KOEHLI, M.; DUDAN, F. et al. Effect of postural changes on certain circulatory and respiratory values in the horse. Am. J. Vet. Res. v.43, p.1003-1005, 1982.

STATISTICAL analysis system.Version 9.1. Cary: SAS Institute, 2004

TAYLOR, P.M. Effects of hypoxia on endocrine and metabolic responses to anaesthesia in ponies. Res. Vet. Sci., v.66, p.39-44, 1999.

TEIXEIRA NETO, F.J. Equilíbrio ácido-base e eletrolítico em anestesia. In: MASSONE, F. (Ed.). Amestesiologia veterinária. Rio de Janeiro: Guanabara Koogan, 201. p.213-226.

YAMASHITA, K.; WIJAYATHILAKA, T.P.; KUSHIRO, T. et al. Anesthetic and cardiopulmonary effects of total intravenous anesthesia using a midazolam, ketamine and medetomidine drug combination in horses. $J$. Vet. Med. Sci., v.69, p.7-13, 2007. 